\title{
EFFECTS OF FOOT REFLEXOLOGY MASSAGE ON REDUCING BLOOD PRESSURE IN ELDERLY WITH HYPERTENSION AT SEKUPANG PUBLIC HEALTH CENTER, BATAM
}

\author{
Martini Heniastaty Patuwondatu ${ }^{1)}$, Cicilya Candi²) \\ ${ }^{1)}$ Student of Faculty of Public Health, Universitas Indonesia \\ ${ }^{2)}$ Lecturer at Faculty of Public Health, Universitas Indonesia
}

\begin{abstract}
Background: Hypertension is significantly associated with increased morbidity and mortality of cerebrovascular diseases, myocardial infarction, congestive heart failure and renal insufficiency. Hypertension is a major public health problem and an important research area due to its high prevalence and a major risk factor for cardiovascular disease and other complications. This study aimed to determine the effect of foot reflexology therapy on lowering blood pressure in elderly people suffering from hypertension in the working area of Sekupang community health center, Batam City.

Subjects and Method: This study was an experiment with a pretest - posttest control group design. A sample of 15 elderlies was selected by simple random probability sampling. The dependent variable was elderly with hypertension. The independent variable was foot reflexology therapy. The data obtained from this study were the values of pre and post therapy blood pressure between the control group and the treatment group. The data was analyzed by Wilcoxon test.

Results: After the intervention of foot reflexology was carried out, foot reflexology affected reducing headache intensity (Mean $=2 ; \mathrm{SD}=0.52)$ and it was statistically significant $(\mathrm{p}=0.002)$. When compared to the control group that was not given therapy, indicating that pain intensity tended to increase with statistical results $($ Mean $=2.33 ; \mathrm{SD}=0.69)$ obtained $(Z$ score $=-2.64)$ with $\mathrm{p}=0.008$.
\end{abstract}

Conclusion: Reducing the intensity of headaches and able to lower blood pressure in older people with hypertension.

Keywords: Hypertension, Foot Reflexology, Elderly, Headache

Correspondence:

Martini Heniastaty Patuwondatu. Faculty of Public Health, Universitas Indonesia. Email : martha.imbuh@gmail.com. 081277466363

The $7^{\text {th }}$ International Conference on Public Health Solo, Indonesia, November 18-19, 2020 | 389 https://doi.org/10.26911/the7thicph.05.21 